\title{
Népi gyümölcsészet és szakszerü gyümölcstermesztés Erdélyben
}

\section{Nagy-Tóth Ferenc}

Amateur and Professional Fruit Production in Transylvania Agriculture and gardening was known by the Hungarians before the year 800 . This was the era of the formation of words like eke, árpa, búza, kender, kömény, torma, kert, gyümölcs, som, alma, körte, dió, szőlö meaning plow, barley, wheat, caraway, horse radish, garden, fruit, apple, pear, nut, grape.

The settling of the Hungarians in the Carpathian Basin influenced the fruit production of the Hungarians especially due to the fact that they renounced to the nomad life and adopted Christianity. The forests, the sloping valleys and the catchments were used together for the production of fruit trees, and this was very benefic for their development, natural selection and reproduction too. The names of the settlements prove the importance of this occupation. Many settlements wear the names of fruits and fruit trees: e.g. almás (54), mogyorós (43), somos (40), körtés (30), diós (20), szilvás (20). These are proper names derived from nouns denoting fruits. (apple, peanut, cornel, pear, nut, plum). The clergy invited from abroad (later innate people but who attended school abroad) had a great impact on the development of the agriculture of a people who now had stable settlements. This was especially due to the cultivation of the gardens of the abbeys and churches. It is important the fact that we have written sources talking about grafting of wild trees thus making them fructify.

The final settlement and the Christian culture influenced the cultivation of the fruit trees using methods like planting and grafting.

This cultivation became even more professional because of the enthusiasm of Rákóczi György I (1593-1648) and his wife, Lórántffy Zsuzsanna (1600-1660), who invited skilled gardeners from abroad. The success is due also to the work of Lippai János (1606-1666), who has edited 
a book about gardening and the cultivation of fruit trees. (Its title: The Garden of Poson vol. I-III.)

The joining of Hungary to the Habsburg Monarchy also had an important effect on the professional and amateur growing and cultivation of the fruit trees. The old and new landowners imported foreign trees without former research or specialized knowledge, many of which proved to be unable to develop because of the climate. The import of these trees slowed down the cultivation of species existing in Hungary and also their selection. The intellectually censored scientific literature chose very often as a topic the agriculture. The wars lead to the destruction of the gardens, and only in remote places had they the chance to survive. In these places the amateur cultivation flourished. The intermingling of the amateur cultivation's rules with those of the professional ones could lead towards a better research of the fruit trees species existing in Hungary only after the spread of specialized literature in Hungarian language. The comparative analysis of home species with those existing abroad funded a basis for scientific research and this flourished till the events of Trianon.

\section{A gyümölcsészet kialakulásának körülményei}

A gyümölcsészet, miként a növénytermesztés is, a gyűjtögetéssel kezdődött. A gyưjtögetés eleinte alkalmi volt, majd rendszeressé vált, hogy aztán a termesztés állandósulásával ismét időkéntivé legyen. E korszakos változásoknak megfelelően bővült a tájban élő ember növényismerete és változott a vidék őshonos és idegen eredetủ haszonnövényeinek összetétele.

Erdélyben az ekés földmủvelés és a gyümölcstermesztés nyomait a rézkorból (Kr. e. 4. évezred) valószínűsítik. Anatóliából bevándorolt népek magukkal hozták az árpa és az alakor, valamint nyugat-ázsiai őshonos gyümölcs termesztését. ${ }^{1}$ A nyugat-ázsiai és közel-keleti haszonnövények nagyobb mérvü Földközi-tengeri és európai elterjedése és meghonosodása a Római Birodalom kialakulásának köszönhető. Ennek hanyatlása után a termesztett gyümölcsök jelenléte a kolostorkertekben és a gyéren megmaradt népi kertekben folytatódott. Ezeknek a kerti növényeknek legteljesebb jegyzéke a Jámbor Lajos rendeletében, a Capitulare de villis et cortis imperiali-

${ }^{1}$ Rapaics R.: A magyar gyümölcs. Kir. Magyar Term. tud. Társulat, Budapest, 1940. Köpeczi B. (főszerk.): Erdély rövid története. Akadémiai Kiadó, Budapest, 1993. 
busban (795) maradt meg. Ebben a jegyzékben 87 növény termesztése volt elrendelve, közöttük 7 almafajta, 3 körtefajta és még néhány cseresznye- és barackfajta van név szerint is megemlítve. ${ }^{2}$

A hazát kereső magyar népnek igen változatos környezeti térségeken megtelepedve ismernie kellett azon helyeknek a megélhetését biztosító természeti adottságait. Közben gyarapodott, csiszolódott az élővilágra vonatkozó ismerete. A Don és Kubán folyók völgyeibe, az Azovi-(Meotisz-)tenger mellékére, a Kaukázus lejtőinek lombos-erdős sztyeppvidékére (Levédia) 800 körül megtelepült magyarság ismerte a földmüvelést. A magyarság Levédia-korabeli krónikása, Ibn Ruszta (Rásztek) feljegyzése szerint „alig lehet kétséges, hogy a magyarok a levédiai földeken szántottak és vetettek". ${ }^{3}$ Itt sajátította el a magyarság a fontosabb élelmiszernövények és gyümölcsfák termesztését. Innen erednek (ótörök közvetítésü) neveik: alma, árpa, búza, dió, gyümölcs, kender, kökény, körte, mogyoró, som, szölö, torma. ${ }^{4}$

\section{A népi gyümölcsészet}

A Kárpát-medencében hazát alapító magyarság természetismerete már megfelelöen gazdag volt ahhoz, hogy az állandó lakhelyhez kötött szántóvető életmódot kibontakoztathassa. A virágporelemzések tanúsága szerint a honalapítás kori Kárpát-medence növénytermesztésre is kedvező szállásterületei meglehetősen korlátozottak voltak. „A Dunától keletre már puszta és emberi megszállás nyomait sem mutató hely volt". ${ }^{\prime 5}$ Erdélynek több mint háromnegyed részét összefüggő zárt erdőségek borították. Máramaros csaknem egész területét „nagy fekete erdő takarta”. ${ }^{6}$ A folyóvizek domboslankás völgyeiben is gyakoriak voltak a ligeterdők és a mocsaras árterek, melyeken, az akkori eszközökkel, nem lehetett földet müvelni.?

\footnotetext{
${ }^{2}$ Rapaics R.: A magyarság virágai. Kir. Magyar Term. tud. Társulat, Budapest, 1932.

${ }^{3}$ Gaál L.: A magyar növénytermesztés múltja. Akadémiai Kiadó, Budapest, 1978.

${ }^{4}$ Gombocz E.: A magyar botanika története. Kiadja a Magyar Tudományos Akadémia, Budapest, 1936. Rapaics 1940: i.m. Róna-Tas A.: A honfoglaló magyar nép. Balassi Kiadó, Budapest, 1996.

${ }^{5}$ Györffy Gy. - Zólyomi B.: A Kárpát-medence és Etelköz képe egy évezred elött. Magyar Tudomány, 1996/8., 899-918.

${ }^{6}$ Giurescu C. C.: Despre istoria pădurii româneşti. = Preda V. (sub. red.): Pădurea şi spațiile verzi în actualitate și perspectivă. Lucrările Simpozionului din 19-20 decembrie 1975. Ed. Acad. R. S. România, Fil. Cluj-Napoca, Cluj-Napoca, 1977. 6-11.

${ }^{7}$ Gaál: $i . m$.
} 
A honalapitás elötti idök népeinek megmủvelt földterületei, gyümölcsös ligetei, ha esetleg léteztek volna, a népvándorlások, háborúskodások következtében, minden bizonnyal tönkrementek. Erdély azon területein, amelyek a Római Birodalomhoz tartoztak annak idején, szervezett gazdasági tevékenység lehetett. „Miután azonban a rómaiak visszavonulni kényszerültek e tájakról, minden visszasüllyedt a régi barbárságba. Még inkább vonatkozik ez a helyzet Dáciára, amelynek gyümölcsészetéröl, szölészetéröl ebből a korból semmit sem tudni."

Az erdőségek, miként az árterek is, eleinte közös használatban voltak, $s$ ennek megfelelően az ott élő haszonnövények, gyümölcsfák is. Ez a köztulajdon természetes volt, hiszen a település közössége gondozta; irtotta az erdőt s közben kiválogatta a hagyásfákat (gyümölcs- és makktermő), szabályozta a „fokok" megnyitásával és elzárásával a belvizeket. ${ }^{9}$ Ezekből a köztulajdonú területekből különültek el a faluközösségi közhasználatú élöföldek („élések”): erdő, legelő, kaszáló, gyümölcsös, nádas, halászó-vizes területek. Ezek a közhasználatú birtokok segítették elő a népi gyümölcsészet kibontakozását, egészítették ki az ott lakó emberek élelmét. És megmaradtak köztulajdonban az úrbéri törvények bevezetéséig (1767).

A honalapítást követő Kárpát-medencei népi gyümölcsészet kibontakozásának kezdeteit és tájankénti elterjedtségét, valamint sajátosságait mindmáig a legmaradandóbban a helynevek tanúsítják. „Az egyes növényfajok, a növényzet szerepe a földrajzinév-adásban vallomás a régebbi növényföldrajzi állapotokról és az idők folyamán végbement változásról." ${ }^{10}$ A magyar nyelvterület 20000 településéből közelítőleg 1000-nek valamely növénynév az alapja, melyekben több mint száz növény neve fordul elö. Az alma neve 54, a mogyoró 43, a som 40, a körte és a dió 30-20 település nevében maradt meg. ${ }^{11} \mathrm{~A}$ településnevek mellett sok gyümölcsnevet őriztek meg a községek határai is (még a később elidegenült helységekben is): Gyümölcsény, Almásróna, Körtvény, Szőlőhegy, Somostető stb. A gyümölcsnevek gyakoriságát, tájbeli elterjedtségük mellett, nyilvánvalóan a gyümölcsök használati értéke is meghatározta. A som bár igen elterjedt és

\footnotetext{
${ }^{8}$ Rapaics 1940: i. m.

${ }^{9}$ Andrásfalvy B.: Ártéri gazdálkodás Magyarországon. História, 2004/4., 15-19., 2004/5. 19-20.

${ }^{10}$ Péntek J.: Népi nevek, népi hagyományok. Mentor Kiadó, Marosvásárhely, 2003.

"Murádin L.: Anyanyelvünk ösvényein. Erdélyi Gondolat Könyvkiadó, Székelyudvarhely, 1996.
} 
írásosan a legelőször említett (1001-ből), mégis ritkábban szerepel a helységnévadásban.

A helységneveket meghatározó gyümölcsök minden bizonnyal vadfajok, többnyire irtások, lecsapolás utáni megkímélt hagyásfák voltak. A kiválogatás, az ösztönös, népi nemesítés, a rendszeres gyüjtögetés és eközben adódott megfigyelések és tapasztalatok folyamányaként, az oltogatásokkal kezdődött. A gyümölcsfák oltás általi szaporítását régóta ismerte az ember. Már Hippokrátesz (Kr. e. 460-377) is említette. Plinius (23-79) A természet históriája címü alapmüvében túlzottnak is tartotta: „nem is helyénvaló, hogy oltásokkal mindenfélét össze-vissza zavarjunk." A Kárpát-medencében megtelepült magyarság körében sem lehetett ismeretlen. Az olt szó a magyar nyelv ugorkori öröksége. Származékai gyakoriak a középkori oklevelekben; egy 1278. évi feljegyzés említ „egy erdőt, melynek népiesen Olthuan a neve" (Unam silvam que vulgariter Olthuan nuncupatur). ${ }^{12}$

Az oltások általi ösztönös kiválogatások, nemesítések eredményezték idővel a tájfajtákat. De az oltások mellett más tényezők is hozzájárultak a gyümölcsök emberi igények szerinti javításához. Az ősi növényzeti együttes kötöttségéből kiszabadított vadgyümölcsfa élettere kiterjedtebb, szabadabb lett, magvai termékenyebb talajba kerültek, elszaporodási esélye javult.

A rendszeresített gyümölcsgyüjtögetés és az ösztönös fajta kiválogatása évszázadokig folytatódott (a gyakori háborús zaklatások miatt bujdokolni készült nép körében). Még Apafi Mihály fejedelem korában (1661-1690) is kötelező volt. Pedig ekkor már létezett Lippai János (1606-1666) Posoni Kert (1664-1667) c. háromkötetes örökbecsủ mủve. A Rákóczi-szabadságharc leverése után a birtokviszonyok megváltoztatását követően a népi gyümölcsészet a magánkertekben folytatódott, a mindinkább korszerüsödő és idegen kertészeti eljárásokat és előnyösebb értékesíthető fajtákat igénylő nagygazdaságokkal egyidejüleg. A kiegyezés (1867) utáni gazdasági fellendülés az idegen gyümölcsfajták termesztésének-terjedésének kedvezett. Ennek ellenére a népi gyümölcsészet is eredményes maradt. A szenvedélyes oltogató és fajtagyüjtő („fajfa”-létrehozó), e kor Kárpát-medencei gyümölcsfajtáinak legjobb ismeröje (közel 500 fajtát írt le a Gyümölcsészeti Vázlatok címü négykötetes múvében) volt Bereczki Máté (1824-1895) is, aki szerint „a gyümölcstenyésztés legszebb és legfontosabb teendője ... az ojtás”.

${ }^{12}$ Benkő L.: (föszerk.): A magyar nyelv történeti-etimológiai szótára. I-III., Akadémiai Kiadó, Budapest, 1976, 1995. 
A népi gyümölcsészet folytonosságát és cselekvő létezését jelen korunkban s az ősi gyümölcsök gyüjtése idején (1951-1956, 2001-2004) is tapasztalni lehetett Erdélyben. Bodokon az öreg tanító úgy szoktatta a falu népét a gyümölcstermesztésre, hogy a határban minden vadfát beoltott. A megfogamzás után "megsúgta a titkot” egy célzatosan kiszemelt gazdának, hozzátéve, hogy ne mondja meg senkinek, nehogy az oltványt elvigyék; jól tudván, hogy az illetö fogja elsajátítani. Ezzel a székely furfanggal rászoktatta és megszerettette faluja népével az ottani természeti feltételekhez jól alkalmazkodott gyümölcsfajták termesztését. Monóban a két világháború közti években egy elismert szakkertész tevékenykedett, aki a korszerü gyümölcsfajtaoltványokat terjesztette. A helybeli gazdák mégis szívesebben termesztették az „oltogató" gazdatársuk által megnemesített, maguk ültette vadcsemetékből serkent régi fajtájú oltványokat. Néhány évvel ezelőtt egyik szorgaimas gazda (Vicsi Mihály) Szilágycsehböl hozott magának „Batur” almafa oltógaillyakat, mivel az ottani almák szebbek az otthoniaknál, Gegesen a tiszteletes maga osztogatta a nemes fáiról metszett oltógallyakat, és oltogatta faluja gazdáinak vadcsemetéit. ${ }^{13}$ Énlaka igazgató-tanítója (Szávai Márton) megalapitotta az erdélyi ősi gyümölcsfajták csemetefa-gyüjteményét, oly eredményesen, hogy Angliába is eljutott a híre, gyümölcstermesztők meglátogatták és oltványokat vittek tőle. Bálványosváralja 1886-ban elfogadott falutörvénye elrendelte egyéb gyümölcstermesztési kötelezettségek mellett, hogy „minden ifjú legény köteles, mielött házasságra lépne, a gyümölcsészeti bizottságának hat darab saját kezüleg ojtott gyümölcsfát számba adni, és számadásakor azt is igazolni, hogy azokat ő maga saját kezüleg ojtotta". ${ }^{14}$ Minden bizonnyal nagyon sok idegen eredetủ gyümölcsfajta is széleskörüen elterjedt Erdély-szerte a népivé vált gyakorlati eljárással. Az idegenböl behozott fajták gallyai helyben maradt vadcsemetékre kerülve lényegesen megváltoztak. Még neveikben is helyi tájfajtákká alakultak. $\mathrm{Az}$ amerikai eredetủ Sárga, szép virágú alma citromalmával honosult $\mathrm{s}$ az őshonos Fejedelmi párishoz vált hasonlóvá.

Az erdélyi népi gyümölcsészetnek és kiválogatásnak, önkéntelen fajtanemesítésnek ez a hagyománnyá szilárdult (már-már pogány felfogásúvá hasonult) hosszadalmas folyamat a jellemzője.

${ }^{13}$ Fülöp G-D.: Feljegyzések Gegesi Kiss Józsefröl. Korunk (Kolozsvár), 1970/1. 156-157.

${ }^{14}$ Egyed Á.: Egy késôi falutörvény. Bálványosváralja gyümölcstermesztési szabályrendelete 1886-ból. = Erdélyi Református Naptár, 2002. 


\section{A szakszerü gyümölcstermesztés}

A szakszerü, természettudományos ismereteket is érvényesítő gyümölcstermesztés meghonosításában alapvető jelentősége volt a magyarság keresztyén hitre téritésének. Ez a kérlelhetetlen határozottsággal létrehozott, jövőbeni békességes megmaradást feltételező életszemlélet döntően határozta meg a létfenntartó foglalkozások állandósulását és tökéletesedését, s általuk az értelmiségi érdeklődés és tevékenység biztató megalapozását is. „A keresztyén tanítás vallásgyakorlat tekintetében egyenlővé tette az embereket ... A papok nem varázslók, akik önkívületi állapotban, vagy állatok belsőiből jövendölnek; maguk is egyszerủ emberek, tanácsokkal szolgálnak, tanítanak, sőt a földmüvelés és gyümölcstermesztés legfontosabb csínja-bínjában is eligazítanak. A társadalmi felemelkedés lehetősége - ha egyházi pályát választott - bárki előtt megnyílt. Jobbágygyerekből is válhatott püspök". ${ }^{15}$ Szerte a Kárpát-medencében kolostorok, templomok épültek (Almás, Batur, Kaplony, Kolozs, Meszes, Szentjobb és még sok), számuk a 12. század végén meghaladta a 600-at. A keresztyéni életfelfogás létrehozásában és terjesztésében különösen a bencés és cisztercita rend monostorai jártak az élen. ${ }^{16} \mathrm{Az}$ egyházi létesítmények szolgálatára rendelt (eleinte idegen, behívott) írástudó papság, a vallásos nevelés mellett, az újszerü, eredményesebb termelőmunka elsajátítását is szorgalmazta. A bencés apátoknak Szent István „ugyanolyan szerepet juttatott az ország megszervezési munkálataiban, mint kétszáz évvel előbb nyugaton a Karolingok (Capitulare de villis)".17

Az idegenből érkezett papság körébe, majd pedig helyébe fokozatosan a letelepedett és feltörekvő népes magyar (nemesi, köznépi) családok külföldön is tanult ifjaiból képzett egyházi vezetők kerültek. ${ }^{18}$ A nyugat-európai országok (Hollandia, Német-, Olaszország) egyetemein tanuló magyar fiatalok (peregrinusok) száma 1520-ig elérte a 2060-at, a fejedelemség korában (1526-1667) pedig a 3000-et. ${ }^{19}$ Ezek a buzgó, hivatásra felkészült fiatalok nemcsak tudást, könyveket és tapasztalatokat hoztak haza, hanem még gyümölcsfaoltógallyakat is. Az egyházi és világi művelődés, nemkülönben

${ }^{15}$ Nemeskürthy I.: Mi magyarok. Akadémiai Kiadó, Budapest, 1993. 95.

${ }^{16}$ Gaál: $i . m$.

${ }^{17}$ Rapaics 1932.: i. $m$.

${ }^{18}$ Köpeczi: $i . m$.

${ }^{19}$ Szabó M. - Tonk S.: Erdélyiek egyetemjárása a korai újkorban. 1521-1700. Közreadja a József Attila Tudományegyetem, Szeged, 1992. 
a mezőgazdálkodás és gyümölcsészet haladását tanúsítják a gyarapodó irásos okmányok. Ezekben egyre gyakoribbak a gyümölcsfajtanevek, amelyek minden bizonnyal korábbiak az őket megörökítő okiratoknál. A „körtvélyfa" említése 1055-től való, de már 1145-böl ismeretes az „apró körtvély”, 1258-ból a „sár (Sárga) körtvély”, 1275-ből a „veres körtvély”, 1287-ből a „telelö körtvély”, 1304-ből a „kalamár körtvély”, 1314-ből a „keserü körtvély”, 1317-böl a „cukor körtvély”, 1326-ból az „árpávalérő körtvély”. Az almafajták közül legkorábban, 1296-ból emlitett „veres alma”, majd 1345-ből a „telelő alma”.

A természetismeretek és ezek keretében a szakszerü gyümölcsészet haladásának eredményeit is az időnként megjelenő és ma is számon tartott írások összegezték. Közülük is kiemelkedő Melius Juhász Péter (1531-1572) Herbariuma (Kolozsvár, 1578), amely szakavatott méltatója szerint: „A hitek és meggyőződések harcában született befejezetlen munka, elindítója egy folyamatnak - a magyar természettudományos, orvosi, botanikai, gyógyszerészeti münyelv, néprajzi adatok nyomtatásában való rögzítésének ... A mezőgazdaságtudomány részére az első kertészeti, állatorvosi, táplálék-, füszer-, és takarmánynövény, és növényvédelmi kézikönyv." ${ }^{20} \mathrm{~A}$ könyvben ismertetett növényfajok száma 1236, akkori népi neveik száma 2000 körüli, többségük jelenleg is ismert és használt. Természettudományos igényénél és jellegénél fogva a termesztett gyümölcsfajok és fajták („Bolondító alma”, „Leán czeczü alma”) csekély számban említettek Melius Juhász Péter könyvében. A korabeli kerti gyümölcsfák (som, „bis”, „monyaró”, dió, alma, "zedery”, „körtve”, cseresznye, meggy, szilva, tengeri barack, „mondola”, barack) leírása megtalálható viszont a Beythe István (1532-1612) közremüködésével készült Clusius C. (1520-1609) Pannónia növényei (Antverpiae, 1584) c. munkájában. Kertészeti-gyümölcsészeti vonatkozásban jelentösebb Szikszai Fabricius Balázs (1530-1576) Szójegyzéke (1590), melyben a fajtanévvel is említett „körtvélyek” („Telelő”, „Árpával érő”, „Muskotály”, „Piros”, „Hosszú szárú”, „Leves”, „Mézes körtvély”) és almák („Eleve érő”, „Telelö”, „Apró piros”, „Mohos”, „Kerekded”, „Lean czeczü”, „Mag nélkül való” stb.) száma megközelíti a félszázat (46). Szikszai 1558-1576 között Kolozsváron is tanított, kortársa volt Melius Juhásznak. Bizonyosra vehető, hogy Szójegyzéke itt is ismert fajtaneveket is tartalmaz. Az általa megörökített gyümölcsfajtanevek szinte mindenike ma is létezik.

${ }^{20}$ Szabó A.: Bevezetô Meliusz Juhász Péter Herbariumához. Kriterion Könyvkiadó, Bukarest, 1978. 


\section{EME}

A szakszerü kertészet és gyümölcsészet erdélyi megalapozásának és kiterjesztésének legkiemelkedőbb cselekvője Lorántffy Zsuzsanna (16001666) és ő általa fejedelmi férje, I. Rákóczi György (1630-1642). A múltat megszépítő eltelt évek tükrében tevékenységük olyannak tủnik, mintha Erdélyt saját kertjüknek tekintették volna. A fejedelem gazdasági ügyekhez való szigora annak a felismerésnek tulajdonítható „hogy Erdély mindenkori fejedelme elsősorban saját családi vagyonára, magánhatalmára támaszkodva tudja megtartani Erdélyt ... A fejedelemasszony megosztott minden gondot elfoglalt férje-urával. Kiterjedt figyelme a gazdaságokra, a vallási kérdésekre, az iskolaügyre éppúgy, mint férjének."21 Szakszerü kertészeti igényüket tanúsítja, hogy az új vetemény-, virágés gyümölcsfajták megszerzésének sürgetése mellett, az idegen, képzett kertészek alkalmazását tartották alapvetőnek. A kolozsvári történelmi levéltárban található adatok szerint (Jakó Zsigmond, Kovács András és Kiss András szíves közlése) 1632 és 1648 között 26 kertész érkezett Erdélybe (még bécsieket is sikerült alkalmazni). Ezek érkezéséről gyakran történik említés leveleikben: „Urunk önagysága hozatott Magiarorsaghbol ... 2 kertészt ...” (1634); „Érkessék két szekér német felleségestől, gyermekestől V. E. N. hossatta kertessenek..." (1541); „Érkezének Trinczenből két szekéren négy új keresztyén kertészek feleségestől, gyermekestől ..." (1642). Ez időben említette Csiki Mihály, a fejedelem gazdasági felügyelője a Pónyik (Pojenics) almát. A sárospataki birtokon volt „Gombos-, Mandulás-, Mogyorós-, Lugas-, Virágos-, Hagymás-, Sáfrányos-, Gyümölcsös-, Oltványos- és Vadaskert". A kertek legtöbbjében természetesen volt szölö is. ${ }^{22}$

A kertészek nemcsak szakismereteiket hozták magukkal, hanem értékesnek vélt haszonnövényfajaikat is. A fejedelem egy 1639. február 27-én kelt levelének utóiratában emlékeztette megbízottját, hogy ne felejtse el megküldeni: „Asszonyunk ő nga számára minemü vörös körtvély jó oltvány ágakat, kik nyárod szaka egy más után szokott meg érni ... Sárospatakon »ighen szép körtveljek " voltak, melyeket megettek a darazsak". Nyilván jó minőségűek lehettek. Számon tartott gyümölcsöskertek voltak az Erdélyimezőség több településén levő majorok mellett is. Jövedelmező kertészkedés folyt Fogarason és a hozzátartozó uradalmakon is.

\footnotetext{
${ }^{21}$ Asztalos M.: Bevezetés. = Makkai I. (szerk.): Erdély öröksége. V. Akadémiai Kiadó, Budapest, 1994.

${ }^{22}$ Nagy-Tóth F. - Fodorpataki L.:: Tündérkertész. Lorántffy Zsuzsanna kertészeti jelentösége. = Tamás Edit (szerk.): Erdély és Patak fejedelemasszonya, Lorántffy Zsuzsanna. II. A Sárospataki Rákóczi Múzeum Füzetei. 41. Sárospatak, 2000. 123-140.
} 
Örök vesztesége a magyar mezőgazdasági szakirodalomnak, hogy a felhalmozódott gazdag tapasztalat és ismeretanyag írásos összefoglalása elmaradt.

Elhivatott szakírója volt viszont a pozsonyi érseki kertnek Lippai János (1606-1666) tudós pap személyében. Virágkorát ez a kert is Lorántffy Zsuzsanna idejében érte el. A kert területét még Oláh Miklós (1387-1437) szerezte meg. Utódai ugyancsak kertbarátok voltak. Közülük Pázmány Péter (1570-1637) is, aki bár szívesen, de keveset kertészkedett. A gyümölcsfákat viszont jól ismerhette, mert még a prédikációiba is beleszőtte, ily módon: "A vad körtvélyből bergamottot vagy kármán körtvélyt nem aszal". A pozsonyi érseki kert Lippay György (1600-1667) korában volt fejlödésének virágában. Korabeli látogatója, a szász-weimari herceg azt írta volt: „Néhány táblában (pomaria) hatalmas alma- és körtefák állanak, nagyon különböző és ritka fajták. Barna- és ezüstszínủ muskotály almafák is." ${ }^{23}$

$\mathrm{Az}$ érsek idejekorán gondoskodott eleven alkotása megörökítéséröl. Testvéröccsét, Lippai Jánost készítette fel, és bízta meg a kert leírásával. Neki köszönhető, hogy „az Nemes Magyar Nemzet közönséges hasznára” írott Posoni Kert három kötete (Virágos Kert, Veteményes Kert, Gyümölcsös Kert) nyomtatásban megjelent. A mü mindmáig a magyar kertészet kincsestára; mind tudományos, mind pedig „istenes szándékbul: az Magyar Kertészeknek oktatásokra, hogy az Hazánk fiai is, a' kik a' gyönyörüséges, és hasznos mesterséget nem-tudják, megtanullják. Ne legyenek a' Magyarok is olly alávalók, hogyha csak közép-szerủ kertészt kévánnak-is, más idegen országokbul kell-hozatniok nagy-költséggel; hanem inkább nem-restelvén az munkát, csak ennek az Könyvnek oktatása által-is az Kertésségben, ha fellyül nem-haladgyák-is más nemzetségeket: legalább ne engedgyenek nekiek".

Lippai János összesen száz - 23 alma, 26 körte, 6 cseresznye, 4 meggy, 10 szilva, 6 őszibarack, 4 kajszibarack, 4 egres, 3 ribiszke - gyümölcsfajtát írt le. Nem törekedett kimerítő fajtaismertetésre, mert jól tudta, hogy „az almáknak külömb külömbféle nemét és nevét mind leírni, majd haszontalannak és lehetetlennek ítélem ... A' körtvélyeknek mind külömbségek, mind nevek majd több, hogy-nem az almáknak". Szakmai jól tájékozottságának bizonysága, hogy amit maga nem látott és meg nem tapasztalt, azt fenntartások nélkül nem fogadta el: „én ez mellett le nem teszem hitemet." Bizton állítható, hogy könyve európai színvonalú szakirodalmi mủ volt, és

${ }^{23}$ Rapaics 1940: i.m. 


\section{EME}

természetesen meghatározó jelentőségủ a Kárpátmedence gyümölcsészetére.

Lippai János Posoni Kertjéhez és Lorántffy Zsuzsanna kertészeti buzgalmához viszonyítva Benedek Enyedi Sándor Kerti dolgok leírása (Kolozsvár, 1669) szerényebb ugyan, mindazonáltal tanúbizonysága lehet a fejedelemség korában, Erdélyben ígéretesen kibontakozott gyümölcsészeti és mezögazdálkodási tevékenységnek. ${ }^{24}$

A sárospataki és pozsonyi kertészeti fellendülés hatására kibontakozott gyümölcsészet haladását meggátolták a bekövetkezett kedvezőtlen történelmi változások. Apafi Mihály fejedelem halála (1681), a Lipót Diploma (1690) érvényesítése, a Rákóczi-szabadságharc kitörése (1703), majd leverése (1711) után Erdély hosszú időre elveszítette önállóságát. Ezek a válságos történelmi események mélységesen megváltoztatták Erdély gazdasági és társadalmi szerkezetét. „A török kiüzése, majd a Rákóczi-szabadságharc elbukása után az ország a legszörnyủbb pusztulás képét mutatta ... Főleg a magyarlakta részek (Alföld, Dunántúl keleti fele, Erdélyben a Mezőség pusztultak el." "Amiolta a németek ott vannak [Bonchidán] a gyümölcsfákat vagdalták... A majorháznak, istállóknak, pajtáknak és gyümölcsöskertnek hasonlóképpen csak a helyei voltanak, és még a gyümölcsfák is csak imitt-amott voltanak..." ${ }^{26}$ A kastélypark csak fél évszázad múltán (1750) újhodott meg. ${ }^{27}$

Az ősi gyökerủ (autochton) gyümölcsészet is visszaesett és inkább csak félreeső, pusztító hadak által nem járható tájak népi kertjeiben folytatódott. Egy Erdőszentgyörgyre vonatkozó 1743. évi okirat tanúsága lehet ennek a lappangva továbbélésnek: „Gyümölcskertben: alma: vajas, muskotálj, mosolygó, páris, cigány, tángyér, apró, piros, fojtós, árpával érő, zsib, fejér, gyakor ágú, édes, brassai, zöld; körtvéj: méz, kerek vagy sárga, téli, muskotáj, sós, elein érő és vackor; szilva: besztercei, husos. lószemű; diófa; szöllö: közönséges bor, muskotáj, kövér, piros, fejér, tök, járdovány, fekete, leány." ${ }^{28}$

A birtokosság (a hatalom által betelepített idegen és az annak behódolt régi) külföldről igyekezett beszerezni még a gyümölcsfákat is, bár a

\footnotetext{
${ }^{24}$ Cseke P.: A magyar nyelvü mezögazdasági irodalom Romániában (1919-1989). = Farkas Z. (szerk.): Adalékok: az EGE-EMGE-RMGE 150 éves történetéhez. Erdélyi Gazda Kiadó, Torda, 2004. 213-226.

${ }^{25}$ Bárczi G.: A magyar nyelv életrajza. Custos Kiadó, Budapest, 1996.

${ }^{26}$ Wesselényi I.: Sanyarú világ. Kriterion Könyvkiadó, Bukarest, 1983.

${ }^{27}$ Rapaics 1940: $i . m$.

${ }^{28}$ Jakó Zs.: Erdőszentgyörgy. = MNMUZ. Rhédey lvt. (Szives közlés).
} 
szakszerü gyümölcsészet hazai feltételei megvoltak. Apáczai Csere János (1625-1659) Magyar Encyclopaedia (1653), valamint Lippai János (16061666) Posoni Kert (1664-1667) c. műveinek adataiból és Lorántffy Zsuzsanna (1600-1660) munkásságából kitünik, hogy az árutermelést is kielégítő gyümölcsészet alapjai, a csemetekert (faiskolák) kezdetei itthon is léteztek. Ezek kifejlesztése helyett a birtokosság külföldröl vásárolta a gyümölcsfaoltványokat. (Tömeges szaporításra a karthauzi barátok [Franciaország] 1675-ben létesítettek jól jövedelmező csemetekertet.) Természetesen még ezúton is csak évtizedek múltán lehetett eredményekröl értesülni (miként az a bonchidai pusztítások helyreállításának fél évszázados időtartamából is megbecsülhető). Nem kétséges, hogy annyi idő múltán már több felújított gyümölcsös is lehetett Erdély-szerte. Írásos emléke azonban kevésnek maradt. Híres volt Bánffy Pál gyümölcsöse, melyet ekképpen ismertettek: „Esmértető könyve méltóságos L. B. Losonci Bánffy Pál úr ő nagysága által külső országokból is megszerzett s a nagycégi és hosszúaszói Erzsébet kertjeiben is található gyümölcsfáknak. Városi Szolga Mihály, a nevezett jószág-inspektora számára írta Orbán Péter az 1812-ik esztendőben." E két gyümölcsösben 149 alma-, 108 körte-, 41 szilva-, 32 cseresznye-, 31 meggy-, 6 őszibarack- és 20 angol egresfajta létezett. Közülük csak 33 volt hazai gyümölcsfajta, mint pl. a Páris alma, a Pónyik alma, a Sóvári alma, a Török muskotályalma, a Nyári borízű alma, a Lőrincz körte, a Zelenka körte. ${ }^{29}$ Elismeréssel írt e gyümölcsösről három évtized múltán az Erdély gyümölcsészetét felmérő Nagy Ferenc is: „Az erdélyi rendszeres gyümölcskertek között, mint a' többek' koronája... a Kolozs megyében kebelezett nagy cégi kert, mellyet n. b. Bánffy Pál tudományos ismerettel, nagy gonddal és költséggel a' mezőség szívében nevelt fel." ${ }^{30}$ Ekkor már Erdély más tájain is létesültek nyugat-európai mintájú, de hazai hagyományokat is felélesztő gyümölcskertek. „Torda vármegyében Abafáján, b. Bornemissza József és Pál, Sárpatakon gr. Teleki Lajos uraknál keressétek a nemes fajú gyümölcsöt. Gr. Telekinél föleg sok alma és különféle terem; 15 év előtt több mint 80 fajt lehetett Sárpatakon találni ... Gr. Kemény József közelebbről épen Párisból hozatott 4-6 éves oltványokat, melyeknek némelyike gerendi csinos kertében már termésbe is indult." ${ }^{31}$

\footnotetext{
${ }^{29}$ Rapaics 1940: i. $m$.

${ }^{30}$ Nagy F. (szerk.): Mentor. Erdélyi népkönyv közhasznú ismeretek tára a' honi szorgalom, 's értelmesedés előmozditására. Előszó 1-5.; Adatoka' honi gyümölcstenyésztésröl. Tilsch és Fia tulajdona. Kolozsváratt, 1842. 57-67.

${ }^{31}$ Nagy F.: (kiadása): Értesités és még valami a Kolozsvárt 1852. December napjaiban tartott
} 


\section{EME}

\section{Tudományosan megalapozott és társadalmilag intézményesített gyümölcsészet}

Néhány gyümölcstermő év tapasztalata kétségtelenné tette, hogy a külföldröl betelepített fajták jó része az erdélyi környezetben nem volt képes kifejteni a nemesítés folyamán szerzett tulajdonságait. „A nyugati országokból már minden kertészet, minden faiskola megrakodott kiválónak mondott fajtákkal ... A fajták élettani tulajdonságait [azonban] nem ismerték." ${ }^{32}$ A nem várt tapasztalat, amely az alaposabb szakirodalmi tanulmányozást is serkentette, jótékonyan hatott a Kárpát-medencei gyümölcsészet megújhodására. E felismerésből eredő kezdeményezés talán legfontosabb eredménye a hazai csemetekertek (faiskolák) létrehozása. Jól tanúsítja ezt a hosszadalmas és költséges kísérletezést Tessedik Sámuel (1742-1820) tevékenysége, aki sokévi munka után tapasztalta (1779), hogy „mivel az idegenből hozott fák nem akartak tenyészni, elkezdtem magról nevelni eper-, alma-, körte-, szilva-, meggy- és galagonyafákat, s ez a kísérletem olyan jól sikerült, hogy már 15000 fát neveltem magról ... Belföldi [fa]iskolák nélkül nem fejlödhet magasra a magyarországi gyümölcstermesztés" ${ }^{\text {"33 }}$

A tudományosan is megalapozott gyümölcsészet elismert múvelöje, „Erdély legkiválóbb gyümölcsésze e korban" ${ }^{\text {"34 }}$ a kései peregrinus, Bodor Pál (1773-1828). Jénai (1795) és göttingai (1796-1797) tanulmányai, majd bécsi gyakorlati tapasztalatai után tért vissza Kolozsvárra (szülövárosába), ahol házsongárdi gyümölcsös kertjében létesített eladásra is szaporító csemetekertet. "El-adó válogatott gyümölcsfa oltványok laistroma” (1812. szept. 1.): 34 alma- (külföldi és hazai), 22 körtvély-, 8 cseresznye-, 3 meggy-, 3 szilva-, 2 barackfajta, naspolya és szeder [eper] oltványfélét ajánlott megvételre. Vele egy időben volt csemetekertje Kolozsváron Cseh Jánosnak (1815), majd még másoknak is. Létesítésük mind gyakoribbá vált, s a 19. század végén Erdély-szerte államilag is kötelezővé tették. Egy 1892. évi kimutatás szerint Kolozsvárt 9 ha-nyi területen 23947 oltott csemete és 60000 vadcsemete létezett; Fogarason 12 ha-on 67000 oltott csemete; Lugoson 17 ha-on 70000 oltott csemete és 100000 vad csemete volt gondozásában. Egy 1894. évi törvénycikk a csemetekertek termesztendő gyümölcsfajtáit is

gyümölcs-kiállitásáról. Kolozsvárt a rom. cath. Lyceum betüivel, 1853.

${ }^{32}$ Rapaics 1940: $i . m$.

${ }^{33}$ Rapaics 1940: i. m.

${ }^{34}$ Rapaics 1940: i. m. 
elöírja, melyek között már sok az ősi eredetű („Batul alma”, „Sóvári alma”, „Sikulai alma”; „Motyó körte”, „Erdei vajonc körte”; „Besztercei szilva”; „Zilahi korai kajszi barack"). ${ }^{35}$

A kisebb települések csemetekertjei rendelkezésileg általában a tanítókra voltak bízva. Ez az intézkedés igen kedvezően hatott mind a szakszerü, mind pedig a népi gyümölcsészetre. A falusi tanító szakmailag is (többé-kevésbé) tájékozott volt, és jól ismerte a falu népét, tudatában volt óvakodásának a hatósági intézkedések és ajánlások iránt. Mint oltogató ember természetesen jó meggyőződéssel ajánlotta a helyi, ősi előnyös fajtákat, de a behozottaktól sem idegenkedett alaptalanul. Ügybuzgalmával, szakmai tájékozottságával megkedveltette közösségével az értelmes gyümölcstermesztést. Gegesen Kiss József „nemes fáiról egész életében ingyen osztogatta az oltógallyakat ... A falvakban elment igen gyakran ő maga a székely gazdákhoz, saját kezével nemesítette fáikat". ${ }^{36}$ Rugonfalva tanítója, Albert András arra szólította fel Kobátfalva és más falvak tanítóit, hogy keljenek versenyre „kinek van szebb faiskolája, több gyümölcsfája, gyümölcsfajtája”. Énlaka tanítója, Szávai Márton ősi fajtákból létesített csemetekertet.

A csemetekertek kialakulását és használatát a gyümölcstermesztés határvonalának tekintették; „vele bezárul a régi familiáris ... gyümölcsgazdálkodás nálunk is, és megkezdődik az üzleti gyümölcsészet." ${ }^{37}$ Az árutermeléses gyümölcstermesztés vonatkozásában, ez valóban döntő változást jelentett. Ám a családi, önellátó, népi gyümölcsészet nem szűnt meg, sőt inkább fejlődött a természeti és gazdasági előnyöknek köszönhetően. Bizonysága ennek a haladásnak az időközben önkéntelen (spontán) kiválogatással keletkezett sok helyi gyümölcsfajta és változat. A családi, önfejlődésü gyümölcsészet végzetes csapását az államosítás jelentette Erdélyben is.

A Habsburg-önkényuralom korlátai között a természettudományok müvelése tünt a legalkalmasabb értelmiségi tevékenységnek. Ez az eszmei irányultság a bécsi kormány szándékainak is megfelelt, mivel politikamentesnek ítélte azt. Ily módon, bár „nem szorosan a felvilágosodás (1711-1830) jellemzője, de most annak lényeges erősítője volt a természettudományok fejlesztése". ${ }^{38}$ A történészek által haladásnak minősített felvilágosodás Erdélyben nem lehetett egyértelmủ. Előnyös volt a szászság részére, kedvező a

${ }^{35}$ Somogyi K. (gyüjt.): Szilágyi vármegye Szabályrendeletei és Közérdekü határozatai. Zilah, Nyom. Seres Samu Könyvnyomdájában, 1907.

${ }^{36}$ Fülöp: $i$. $m$.

${ }^{37}$ Rapaics 1940: $i . m$.

${ }^{38}$ Köpeczi: $i . m$. 
románság terjeszkedésére (jelentős birtokadományok, határőrezredek szervezése, iskolák és müvelődési intézmények létesítése, népességnövekedés; 1700-1761 között 250 000-ről 547 000-re), a magyarság számára viszont sok vonatkozásban hátrányos, korlátozó volt. Az önkényesen elrendelt intézkedések közül a legfájdalmasabb az anyanyelv korlátozása volt. Márpedig: „Valamennyi erdélyi értelmiségi nemzedék a kor adta lehetőségek keretén belül kifejezésre juttatta azt a szilárd eltökéltséget, hogy ragaszkodik a tudományok egészének magyar nyelven való mủveléséhez, és a feltárt tudományos igazság anyanyelven való terjesztéséhez." ${ }^{39}$ A megkülönböztető (diszkriminatív) kormányzati körülmények helyezték előtérbe a természettudományok mủvelését a 18. századi erdélyi magyarság körében.

$\mathrm{Az}$ anyanyelvü tudományművelés legkiemelkedőbb teljesítménye e korból Pápai Páriz Ferenc (1649-1716) Pax corporisa (1690). Rendszerezett orvostudományi szakkönyvként közvetlen hatása maradandó volt, és némely helyeken (a moldvai csángók körében) még a 20. században is használták. Közvetett, anyanyelvü müvelődési értéke felbecsülhetetlen. A természettudományok művelése vonatkozásában jelentős megvalósításnak számított a Societas Agriculturae (Mezőgazdasági Egyesület) létrehozása, mégha csak az 1769-1772. évek között müködött is. Ennek keretében fejtette ki (igaz csak latinul) erdélyi munkásságát a kenyérsütésről, a sörés pálinkafőzésről, a papírgyártásról és bőrcserzésről Frivaldszky János (1730-1784)..$^{40}$ Erdély legnagyobb természettudós-botanikusa e században a középajtai református pap, Benkő József (1740-1814), akinek főmüve a Transsilvania sive Magnus Transsilvaniae Principatus (Erdély avagy Erdély Nagyfejedelemsége) (1778). Leírásában a gyümölcsöket is számbavette: „A különböző fajú termesztett alma- és körtefajták Csik- és Gyergyószék mellett és más tájak mezőin Erdély-szerte majd mindenütt gyakoriak ... igazából azonban Udvarhelyszék, melynek falvai többnyire beültetett gyümölcsösökben, almákban, körtékben, szilvákban, dióban, édes- és savanyú meggyekben, továbbá párisi és hasonló négy vagy öt almafajtákban hasonlóan bővelkednek." ${ }^{11}$ A kormányhatóságok a gyümölcsösök telepítése mel-

\footnotetext{
${ }^{39}$ Benkő S.: A romániai magyar tudomány helyzete és az Erdélyi Múzeum-Egyesület feladatai. Budapest, 1993. 1-11.

${ }^{40}$ Csetri E. - id. Frivaldszky J.: A köz hasznára - az ég kegyelmével. Magyar Egyháztörténeti Enciklopédiai Munkaközösség (METEM), Budapest, 2003. 5-160.

${ }^{41}$ Benkő J.: Transilvania, sive magnus Transsilvaniae principatus. Vindobonae, Typis Iosephi nob. de Kurzbök, 1778.
} 
lett különösen az eperfák ültetését szorgalmazták, mely a nagyon pártfogolt selyemhernyó-tenyésztéséhez kellett.

Jelentős kezdeményezés volt a Pete Ferenc szerkesztésében 1796. január 1-én, az akkori önkényuralmi körülményekre jellemzően Bécsben megjelent első magyar nyelvű mezőgazdasági folyóirat, a „Magyar Újság, melly Magyar és Erdély Országban a Mezei gazdaságot és szorgalmatosságot erányozza".42

Nem kétséges, hogy ebben a válságos történelmi időszakban megjelent természettudományos munkák (még ha idegen nyelven is), valamint szerzőik közéleti tevékenysége jelentősen hozzájárultak a (népi és szakszerü) gyümölcsészet haladásához is.

A mezőgazdaság, különösképpen a gyümölcsészet ismeretelméleti, tudományos megalapozása a reformkori felvilágosult értelmiségiek következetes munkálkodásának köszönhetö. Az ösztönzö gyökerek Széchenyi István (1791-1860) Hitel (1830) c. müvének eszméiből, az általa kezdeményezett Országos Magyar Gazdasági Egyesület megalakulásából (1835), illetőleg a Mikó Imre (1805-1876) alapította Erdélyi Gazdasági Egyesület (1844) tevékenységéből sarjadtak ki. „A Hitelnek nagy visszhangja támadt, az akkoriban kibontakozó reformmozgalom programjává vált."

Az Erdélyi Gazdasági Egyesület létesítése nemcsak a reformeszmék, hanem az előző évszázad meggátolt törekvéseinek (Societas Agriculturae) letéteményese is. Ezeknek köszönhetően volt oly lendületes. A múlt fájdalma egyik céljában is visszacseng: „,... a gyümölcstermesztés- és szőlőmivelés javítása ez újabb időkben sokképpen vált fontossá: szőlőinknek, gyümölcsöseinknek a táborozások által országszerte kipusztítása." ${ }^{43} \mathrm{Az}$ Egyesület elnöke Erdély Széchenyije, Mikó Imre, titkára „Erdély büszkesége",44 Nagy Ferenc alapító, tagjainak egyike pedig a csemetekert-létesítő Bodor Pál (1773-1828).

A gyümölcsösök felújitásának, megalapozásának gyorsabb megvalósítása csak a nagybirtokosoknak és a kivételezett szászoknak kedvezett, „a napi kivánatok közt alig van sürgetőbb, mint a' honi köznépet - a' nagy tömeget, a' munkás dolgozó néposztályt nyomorából 's tudatlanságából ki-

\footnotetext{
${ }^{42}$ Cseke: $i . m$.

${ }^{43}$ Tokaji L.: Gróf Mikó Imre és a magyar föld = Erdélyi P. (szerk): Emlékkönyv az Erdélyi Múzeum-Egyesület félévszázados ünnepére, 1859-1909. Az Erdélyi Múzeum-Egyesület kiadása, Kolozsvár, 1909-1942. 271-284.

${ }^{44}$ Bereczki M.: Gyümölcsészeti vázlatok I-IV. Nyomtatott Gyulai Istvánnál Aradon és Pesti Lloyd-Társulatnál, Budapest, 1877-1887.
} 
emelni igyekezni. Sürgetőnek mondjuk e' kivánatot, mert utoljára is a' nagy néposztály jólléte, 's mivelődése azon alap, mellytől az ország fölvirágzása 's erői függnek. Kevesek jólléte, 's milliók szegénysége, néhánynak magas vagy középszerü képzettsége, 's ezerek kiáltó tudatlansága arany paszománt czondraposztón, selyemhímzés rongyos ruhán ... Elődeink a' nemes gyümölcsöket méltó becsben láttattak tartani, minek tanusága az ismeretes kifejezés »nékem is van öt-hat szilvafám « mellyel némellyek birtokosi állapotukat mintegy hetykélkedve szokták kijelenteni ... A nemes gyümölcsök a' közvéleményben úgy állanak, mint csemege 's nyalánkság,... A dolog erét eltaláltuk, ha a' nemes gyümölcsfa-szaporítás körüli országos hanyagságnak, 's a' gyümölcs' nem eléggé becsben tartásának okát abban keressük, hogy ezt a' közvéleményben, fontos gazdasági czikknek nem tekintik ... A gyümölcs ... sok szegény, különösen falusi honfitársainknak kenyér mellett a' leves étek' helyét igen jótékonyan pótolná, ha azzal bővölködnék ... A nemes gyümölcsfa szaporítása a legnagyobb jótétemény lenne különösen a' föld népe' szegényebb osztályára nézve".45

A szakszerủ gyümölcstermesztés fellendítése nagymértékben Nagy Ferenc (1804-1876) kolozsvári gimnáziumi, majd kolozsmonostori gazdasági tanintézeti tanárnak az érdeme. Az ő első országos felméréséből ismeretes, hogy „a marosszéki páris almának országos híre 's becse van... Jó gyümölcs az ugy nevezett mosolygó alma is, szép külsőjủ és nagyon leves ... A marosszéki cseresznyék közt igen jó a' hólyagos cseresznye, melly főleg a’ Nyárád mentén bőven terem ... Torda vármegyében Abafáján, ... Sárpatakon ... keressétek a' nemes faju gyümölcsöt. Van a tordai szölőkben két neme az almának, az eperalma és a francia muskotály (Tordán narancsalma), mellyek ott nagy mennyiségben tenyésznek ... Az algyógyi járásban Máda nevü helység sok és jó gyümölcsöt terem, s' lakossai azzal keresik élelmöket. Itt terem a híres mádi alma és cseresznye ... Alsó Fehér megyében ... legnevezetesebb az úgy nevezett gyógyi alma, melly verescsikos, hosszukó ... Doboka vármegyében Árokalja érdemel emlitést, hol föleg sok pojnyik alma terem ... Közép-Szolnok és Kraszna megyékben mindenfajta gyümölcs bőven terem ... Zilahon ... híres, de rossz sóvári alma is nagy mennyiségben terem ... Legnevezetesebb Szilágyban a' gyümölcs tenyésztésre, mint sok egyebekre nézve is, Zsibó: nemes alma-, körtefákkal az egész uradalom bé van ültet$\mathrm{ve}^{\prime \prime 4}$

\footnotetext{
${ }^{45}$ Nagy F. 1842: i.m.

${ }^{46}$ Nagy F. 1853: $i . m$.
} 


\section{EME}

A szakszerü gyümölcstermesztés serkentése és népszerüsítése, nemkülönben a fajtaazonosítás és fajtaminősítés tekintetében igen fontosak voltak a gyümölcskiállítások, a "gyümölcsizlelések”, amelyeknek ugyancsak Nagy Ferenc volt a kezdeményezője és megszervezője. Meghatározó jelentőségünek bizonyult gyümölcsészeti, de társadalmi vonatkozásban is, az 1852. évi decemberi kiállítás, amely némi dicsekvést is kiváltott. „Miután a vidékröl kevés kivétellel, szinte semmi sem küldetett be ... egészében véve kolozsvári gyümölcskiállításnak nevezhetjük ...

Ilyen körülmények között képesek voltunk közel 160 darab külön faj alma, és 33 téli körte fajokat kiállítani, tehát a legelső kísérleti alkalommal is csak Kolozsvárról többet állítottunk ki, mint 1850-ben dr. Entz Pestről és vidékéről"47

\section{Összegezés}

A reformkorban élénkülő magyar, s ennek keretében az erdélyi gyümölcsészet (népi és szakszerủ, tudományosan megalapozott egyaránt) - váltakozó hullámzással és kölcsönös kiegészítésekkel haladva évszázadok folyamán - csak a kiegyezés után volt képes kiteljesedni és általánosan közérdekủ gazdasági ágazattá megszerveződni. Fejlődése az I. világháború kitöréséig tartott. Sőt még a trianoni csapás után is erre alapozódott. Ezt a fél évszázadot tekintik a magyar gyümölcsészet virágkorának.

${ }^{47}$ Nagy F. 1853; $i, \mathrm{~m}$. 